\title{
Phytoremediation, a Biotechnology with Important Applications
}

ISSN: 2637-7659

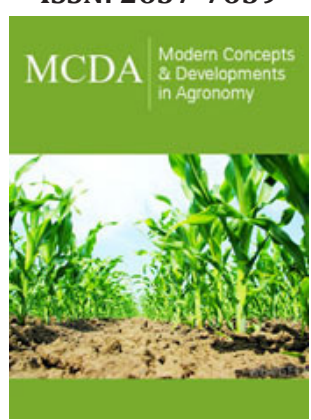

*Corresponding author: Vanesa Pérez Cuadra, Argentina

Submission: 㭗April 10, 2019

Published: 此April 17, 2019

Volume 4 - Issue 1

How to cite this article: Vanesa P C, Martín E. Phytoremediation, a Biotechnology with Important Applications. Mod Concep Dev Agrono.4(1). MCDA.000578.2019.

DOI: 10.31031/MCDA.2019.04.000578

Copyright@ Vanesa Pérez Cuadra, This article is distributed under the terms of the Creative Commons Attribution 4.0 International License, which permits unrestricted use and redistribution provided that the original author and source are credited.

\author{
Vanesa Pérez Cuadra1 ${ }^{1,2 *}$ and Martín Espósito ${ }^{3,4}$ \\ ${ }^{1}$ Depto Biología, Argentina \\ ${ }^{2}$ CCT BB-INBIOSUR UNS-CONICET, Argentina \\ ${ }^{3}$ Departamento de Agronomía, Argentina \\ ${ }^{4}$ CGAMA UNS-CIC, Argentina
}

\section{Introduction}

The pollutants found in the environment, of natural origin and as a result of human activity, generate a negative impact on ecosystems. The resolution of this type of problems through the application of environmentally friendly technologies are of extreme necessity, one of these technologies is phytoremediation. Pollution with different types of substances has become a phenomenon of great importance because it affects air, water and soil, also disturbing all the ecosystems that develop in them, including humans. Although some contaminants are of natural origin, through the degradation of materials of the earth's crust, but human activities greatly increase the occurrence of certain other contaminants [1,2]. Water pollution is especially important because this pollution often affects freshwater sources, many of which are used for human and animal food. The contamination of water by arsenic (As), fluorine (F), boron (B), vanadium (V), cadmium (Cd), heavy metals, nutrients and organic constituents is of particular concern [3]. In addition to the direct impact of water consumption with excesses of different toxic elements in public health, it must be considered the transfer of the toxic elements from water to crops and from crops to livestock, generated in this way their subsequent incorporation into the human food chain through cereals, vegetables, milk and meats $[4,5]$.

Water treatment plants include water removal systems of different elements especially toxic for humans, however, in many cases the treatments for removal of toxic elements are extremely expensive, which means that people from undeveloped countries, rural areas or towns with few inhabitants cannot access to them, being exposed to severe health problems $[6,7]$. In response to this need, alternative techniques for the elimination of contaminants from water become increasingly important, with special attention paid those that involve the use of plants [6,8-12]. These techniques, called phytoremediation, are a method of removal of various pollutants used successfully since several years ago in the world [13].

Phytoremediation is applied to eliminate, or diminish, harmful components through the use of plants that have specific capacities to absorb contaminants. The term phytoremediation, used for the first time in 1991 [14], is a technique that uses plants to degrade, contain, extract or immobilize soil or water pollutants, widely studied due to its good cost-effectiveness ratio and absence of adverse implications for the environment $[15,16]$. Phytoremediation is still in research and development phase, with many technical issues needing to be addressed [1], for example most of the experiments have taken place on a laboratory scale, with plants grown in hydroponic settings fed heavy metal diets, so in this sense agronomic management practices and plant genetic abilities need to be optimized to develop commercially useful practice [1]. Although in recent years there have been more investigations that provide innovative data in the application of these technologies $[17,18]$. The most important factor for the phytoremediation process to be successful is a suitable plant species which can be used to uptake the contaminants [18]. However, phytoremediation has some technical limitations, and in this way information is needed to consolidate phytoextraction into a cost-effective 
method [19]. When the remedial plants manage to establish themselves in large areas, they help to return utilitarian and/or economic potential to the environment, in addition to modifying the aesthetics of the landscape of the contaminated sites [19].

\section{Conclusion}

It is essential optimize phytoremediation to ensure water quality in order to begin to reduce the negative impact of some of the contaminants present in the food chain. Generating information on water phytoremediation will be extremely useful for professionals who practice preventive medicine, for agronomic irrigation projects, as well as for the relevant authorities related to the management of water resources, given their responsibility in the delivery and distribution of drinking water to the most affected sectors.

\section{References}

1. Padmavathiamma PK, Li LY (2007) Phytoremediation technology: Hyper-accumulation metals in plants. Water, Air and Soil Pollution 184(1-4): 105-126.

2. Blanco MC, Florentino CE, Paoloni JD, Sequeira ME, Espósito M (2007) Litologías y calidad de aguas superficiales y subterráneas: Incidencia en el hidroarsenicismo de la región pampeana sur. Abstracts II Taller sobre arsénico en aguas V Congreso Hidrogeológico Argentino, Paraná, Argentina, pp. 93-98.

3. Espósito ME (2014) Hidrología e hidroquímica de la cuenca del arroyo El Divisorio, Provincia de Buenos Aires, Tesis Doctoral, Universidad Nacional del Sur, Bahía Blanca, Argentina.

4. Hilbe N, Brusa L, Beldoménico H, Sigrist M (2014) Total arsenic levels by flow injection hydride generation atomic absorption spectrometry in selected food from Santa Fe, Argentina. One century of the discovery of arsenicosis in Latin America (1914-2914). Arsenic in the Environment Proceedings, Section 3-Arsenic and health exposure. CRC Press-BalkemaTaylor and Francis, pp 412-413.

5. Martinis EM, Willoud RG (2014) Arsenic in grape juice from Mendoza, Argentina. One century of the discovery of arsenicosis in Latin America (1914-2914). Arsenic in the Environment Proceedings, Section 3Arsenic and health exposure. CRC Press- Balkema-Taylor and Francis, pp. $472-474$.
6. Litter MI, Morgada ME, Bundschuh J (2010) Possible treatments for arsenic removal in Latin American waters for human consumption. Environ Pollut 158(5): 1105-1118.

7. Tokunaga S, Hakuta T (2002) Acid washing and stabilization of an artificial arsenic-contaminated soil. Chemosphere 46(1): 31-38.

8. Singh R, Singh S, Parihar P, Singh VP, Prasad SM (2015) Arsenic contamination, consequences and remediation techniques: A review. Ecotoxicol Environ Saf 112: 247-270.

9. Ma LQ, Komar KM, Tu W, Zhang C, Cai Y, et al. (2001) A fern that hyperaccumulates arsenic. Nature 409: 579.

10. Nakwanit S, Vissottiviseth P, Khokiattiwong S, Sangchoom W (2011) Management of arsenic-accumulated waste from constructed wetland treatment of mountain tap-water. J Hazard Mater 185(2-3): 1081-1085.

11. Rahman M, Hasegawa H (2011) Aquatic arsenic: Phytoremediation using floating macrophytes. Chemosphere 83(5): 633-646.

12. Rahman S, Kim KH, Saha SK, Swaraz AM, Paul DK (2014) Review of remediation techniques for arsenic (As) contamination: A novel approach utilizing bio-organisms. J Environ Manage 134: 175-185.

13. Dickinson NM, Baker AJM, Doronila A, Laidlaw S, Reeves RD (2009) Phytoremediation the inorganics: realism and synergies. Int J Phytoremediation 11(2): 97-114.

14. Licht L (1995) Perennial plant systems using poplar trees for managing priority pollutants at landfills and industrial sites. In: Teddar DW (Ed.), Emerging technologies in hazardous waste management VIII, Extended abstracts for the special symposium, Atlanta, USA.

15. Krämer U (2005) Phytoremediation: Novel approaches to cleaning up polluted soils. Curr Opin Biotechnol 16(2): 133-141.

16. Reeves RD, Baker AJM (2000) Metal-accumulating plants. In: Raskin I, Ensley BD (Eds.), Phytoremediation of toxic metals: using plants to clean up the environment, John Wiley \& Sons, New York, USA.

17. Pérez Cuadra V, Cambi V, Espósito M, Sica MG, Verolo M, et al. (2019) Senecio bonariensis Hook. \& Arn. promIsing arsenic phytoextractor from water in laboratory and field trials. Emerging Contaminants 5: 1522.

18. Tangahu BV, Abdullah SRS, Basri H, Idris M, Anuar N, et al. (2011) A review on heavy metals (As, $\mathrm{Pb}$ and $\mathrm{Hg}$ ) uptake by plants through phytoremediation. International Journal of Chemical Engineering p. 31.

19. Jabeen R, Ahmad A, Iqbal M (2009) Phytoremediation of heavy metals: Physiological and molecular mechanisms. Botanical Review 75(4): 339364.

For possible submissions Click below: 